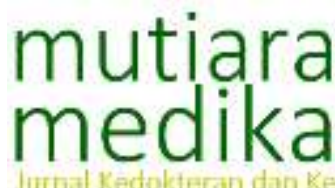

Mutiara Medika: Jurnal Kedokteran dan Kesehatan http://journal.umy.ac.id/index.php/mm

Vol 21 No 1 Page 32-38, January 2021

\title{
Correlation the Density of Dermatophagoides sp. in Households with the Score for Allergic Rhinitis in Jember, East Java
}

\author{
Hubungan Kepadatan Dermatophagoides sp. di dalam Rumah dengan Skor Rinitis Alergi di Jember, \\ Jawa Timur \\ Erma Sulistyaningsih ${ }^{1}$, Elisa Fadia Laili ${ }^{2}$, Cholis Abrori ${ }^{2}$ \\ ${ }^{1}$ Department of Parasitology, Faculty of Medicine, University of Jember. Jalan Kalimantan 37 Kampus Bumi Tega Boto \\ Jember 68121 \\ 2 Faculty of Medicine, University of Jember, Jalan Kalimantan 37 Kampus Bumi Tega Boto Jember 68121
}

DATA OF ARTICLE:

Received: 3 Jan 2020

Reviewed: 25 Jun 2020

Revised: 19 Nov 2020

Accepted: 05 Dec 2020

\section{*CORRESPONDENCE:}

sulistyaningsih.fk@unej.ac.id

DOI:

10.18196/mmjkk.v21i1.7925

TYPE OF ARTICLE:

Research
Abstract: The prevalence of allergic rhinitis (AR) in Indonesia is an estimated 24.3\% and increasing each year. The majority cause of AR is house dust mites (HDMs) allergens, especially Dermatophagoides sp. The screening tool to estimate the prevalence and diagnose AF in a population setting is the Score for Allergic Rhinitis (SFAR) questionnaire. This study aimed to investigate the correlation between the density of Dermatophagoides sp. in households and the SFAR in Jember, East Java. The study enrolled 30 housewives as respondents, which were selected by stratified random sampling. Respondents were interviewed using the SFAR questionnaire. The dust sample from each house of the respondent was collected, the HDMs either Dermatophagoides sp. or others were identified and the density of Dermatophagoides sp. was calculated. Data were analyzed using the Pearson Test. Dermatophagoides sp. were found in 21 out of 30 samples and 11 out of 30 respondents had an SFAR of $\geq 7$. The Pearson analysis showed the value of $\mathrm{p}=0.555$ and $\mathrm{r}=0.136$. Dermatophagoides $s p$. was the majority of species of HDMs, but there was no significant correlation between the density of Dermatophagoides sp. in households and the SFAR among housewives in Jember.

Keywords: allergic rhinitis; Dermatophagoides sp; house dust mites; SFAR

Abstrak: Prevalensi rinitis alergi $(A R)$ di Indonesia diperkirakan 24,3\% dan cenderung meningkat setiap tahun. Penyebab AR mayoritas adalah alergen tungau debu rumah (HDM) terutama Dermatophagoides sp. Alat skrining untuk memperkirakan prevalensi dan mendiagnosis AF dalam pepopulasi adalah kuesioner Score for Allergic Rhinitis (SFAR). Penelitian ini bertujuan untuk mengetahui hubungan antara kepadatan Dermatophagoides sp. di rumah tangga dan SFAR di Jember, Jawa Timur. Penelitian ini melibatkan 30 ibu rumah tangga sebagai responden yang dipilih secara stratified random sampling. Responden diwawancarai menggunakan kuesioner SFAR. Pengambilan sampel debu dari rumah masingmasing responden. HDMs baik Dermatophagoides sp. atau yang lainnya diidentifikasi dan selanjutnya kepadatan Dermatophagoides sp. dihitung. Data dianalisis menggunakan Uji Pearson. Dermatophagoides sp. didapatkan sebanyak 21 dari 30 sampel yang diambil dan 11 diantara 30 responden memiliki SFAR $\geq 7$. Analisis Pearson menunjukkan nilai $p=$ 0,555 dan $r=0,136$ yang menunjukkan bahwa tidak terdapat korelasi yang bermakna antara kepadatan Dermatophagoides sp. dengan SFAR ibu rumah tangga di Jember.

Kata kunci: rhinitis alergi, Dermatophagoides sp, tungau debu, SFAR 


\section{INTRODUCTION}

Allergic rhinitis (AR) is a symptomatic disease of the nose due to the inflammation of the nose caused by an allergen. It is very common condition in four seasons countries, estimated to affect around one in every five people in the United Kingdom. The prevalence of AR in Latin America was 5.5-45.1\%, Europe was 23-30\%, Africa was $7.2-54.1 \%$, Australia was $12-41.3 \%$ and South-East Asia was $5.5-44.2 \%{ }^{1}$ The prevalence of AR in Indonesia variable, it is estimated $24.3 \%$ and tends to increase each year. ${ }^{2}$ Although AR is not commonly a severe complaint, it has a negative impact on patients social lives, the school performance of children, and productivity in the workplace. ${ }^{3}$

The cause of more than $50 \%$ of AR in Indonesia is house dust mites (HDM), and Dermatophagoides pteronyssinus (Der p1), and D. farinae Der $\mathrm{f}_{1}$ ) is the most common HDM allergen. ${ }^{4}$ The external part of the body, part of the body and feces of Dermatophagoides sp. contains Der p1 and Der f1 allergens which can activate the $A$ and $D$ proteins on the lung surfactant that can inhibit the binding of allergen to IgE. The Der 1 also can induce the production of proinflammatory cytokines through proteinase-activated receptor 2 (PAR2) independent in the respiratory tract and stimulate the development of Th2, which further activate $B$ cell to produce IgE. IgE and allergen's binding causes degranulation of mast cells and basophil to release histamine, resulting in the symptoms of AR. ${ }^{5}$ The symptom of AR includes the runny or stuffy nose, sneezing, red, itchy and watery eyes, and swelling around the eyes. Exposure to $100-500 \mathrm{HDM} / \mathrm{g}$ of dust or $10 \mathrm{mg}$ Der p1/g is a risk factor for an allergic reaction. Exposure to $500 \mathrm{HDM} / \mathrm{g}$ of dust in a long time results in IgE-antibody responses. ${ }^{6,7,8}$

The prevalence of RA in developed and developing countries tends to increase. However, there is limited assessment available to diagnose, especially in population settings, where there are no objective allergy measurements and no health professionals. The Score for Allergic Rhinitis (SFAR) is a quantitative questionnaire developed by experts as a helping tool to diagnose AR. The questionnaire has been validated in three different ways, i.e., diagnosis validation by the medical specialist, internal validation using psychometric methods, and population acceptability methods. ${ }^{9}$ Study in France and six African countries on using the SFAR to diagnose AR reported that the SFAR gives the same or higher positive predictive value and specificity as the International Study of Asthma and Allergies in Childhood (ISAAC) questionnaire. The study also showed that nonspecialists could use the SFAR without performing a physical examination, and the AR diagnosis was nearly matched with the gold standard's diagnosis, confirmed by skin prick test. This questionnaire has eight components, including (1) nasal symptoms in the past year, i.e., sneezing, runny nose and blocked nose; (2) nasal symptoms accompanied with itchy-watery eyes; (3) month of the year that the nasal symptoms occur; (4) triggers of nasal symptoms (pollens and house dust); (5) allergic status; (6) previous diagnosis of allergy; (7) previous positive allergy test; and (8) familial history of allergy. A total score of SFAR is 16 , and the cutoff value of $\geq 7$ can differentiate individuals with and without $A R .^{10,11}$

There were some studies on the density of house dust mites, allergic rhinitis and its symptoms in association with the attitude and practice, ${ }^{12,13,14}$ but no study using the SFAR questionnaire to measure the allergic rhinitis, especially among housewives. This study aimed to determine the correlation between the density of Dermatophagoides sp. in households and the SFAR among housewives in Jember, East Java.

\section{MATERIAL AND METHOD}

\section{Study design and ethical clearance}

The study was a cross-sectional study and was conducted in Jember, Indonesia. The study's procedure has been approved by the Ethical Committee of Faculty of Medicine, University of Jember, with reference number $1281 / \mathrm{H} 25 \cdot 1.11 / \mathrm{KE} / 2019$. The sample was chosen by stratified random sampling. We enrolled 30 housewives, which match with inclusion criteria, i.e., 21-34 years old, do not have an outside job, and signed the informed consent after explanation. We excluded women who have a pet such as dogs, cats or birds, and living with a smoking family member. The inclusion criteria for collected house dust were dust from a 1-yearold or older mattress, dust from a mattress that has not been dried in the past week, and dust from a mattress with more than three days of bedsheet replacement. The exclusion criteria were dust from the mattress, which was still wrapped in plastic and made from cotton.

\section{Data collection}

We collected dust samples at each house by using a $350 \mathrm{~W}$ vacuum cleaner. Dust was collected from a mattress in an area of $1 \mathrm{~m}^{2}$ for 2 minutes. The collected dust was placed into a ziplock and labeled with the 
Vol 21 No 1

January 2021

respondent's code and sampling date. This study interviewed a housewife at each house using the SFAR questionnaire.

Dust samples were transported to the Laboratory of Parasitology, Medical Faculty, University of Jember. Each dust sample was weighed and recorded. As much as $0.1 \mathrm{~g}$ of dust sample was diluted with distilled water and observed under a stereoscopic microscope. Each HDM found was taken using a mite needle and fixed using Hoyer's medium on object glass. The fixed HDM was identified using a light microscope based on Collof key of identification ${ }^{15}$ and consulted with the entomologist of the Biology Department, Faculty of Mathematics and Natural Sciences, University of Jember. The identification of HDMs in this study only reached the genus stage. The density of Dermatophagoides sp. were calculated using the following formula. ${ }^{16}$

$$
\text { HDMs density }=\frac{\text { mass of dust }(g)}{0.1} \times \text { HDMs found in } 0.1 \mathrm{~g} \text { of dust }
$$

\section{Statistical Analysis}

The data was analyzed for its normality using Shapiro-Wilk. Data was transformed once before it had a normal distribution. P-value was used to analyze the significant criteria. The correlation test was performed using Pearson Test

\section{RESULT}

There are 30 respondents involved in this study. The result of the interview showed that All job at the time. The majority of respondents were $25-29$ years old women (46.67\%), as shown in Table 1.

Table 1. The Distribution of Respondents' Age

\begin{tabular}{ccc}
\hline Age (years) & Total (n) & Percentage (\%) \\
\hline $20-24$ & 5 & 16.67 \\
$25-29$ & 14 & 46.67 \\
$30-34$ & 11 & 36.67
\end{tabular}

Table 2. Identification of HDMs in Dust Samples, its Density and the SFAR's Score of Respondents

\begin{tabular}{|c|c|c|c|c|c|c|}
\hline Code & $\begin{array}{c}\text { Dust } \\
\text { mass }(\mathrm{g})\end{array}$ & $\begin{array}{l}\text { Number of } \\
\text { HDM found } \\
\text { (n/ } 0.1 \mathrm{~g} \text { of } \\
\text { dust) }\end{array}$ & $\begin{array}{l}\text { HDM density } \\
\text { (n/g of dust) }\end{array}$ & $\begin{array}{c}\text { Number of } \\
\text { Dermatophagoides sp. } \\
\text { found } \\
\text { (n/0.1 g of dust) }\end{array}$ & $\begin{array}{c}\text { Dermatophagoides sp. } \\
\text { density } \\
\text { (n/g of dust) }\end{array}$ & SFAR \\
\hline 01 & 1.3 & 13 & 169 & 1 & 13 & 6 \\
\hline 02 & 0.5 & 8 & 40 & 1 & 5 & 0 \\
\hline 03 & 0.8 & 0 & 0 & 0 & 0 & 0 \\
\hline 04 & 0.8 & 5 & 40 & 2 & 16 & 12 \\
\hline 05 & 3.7 & 5 & 185 & 1 & 37 & 6 \\
\hline 06 & 0.9 & 5 & 45 & 2 & 18 & 7 \\
\hline 07 & 0.3 & 7 & 21 & 0 & 0 & 5 \\
\hline 08 & 0.9 & 14 & 126 & 1 & 9 & 11 \\
\hline 09 & 0.9 & 16 & 144 & 3 & 27 & 11 \\
\hline 10 & 0.4 & 4 & 16 & 0 & 0 & 6 \\
\hline 11 & 0.6 & 15 & 90 & 2 & 12 & 12 \\
\hline 12 & 0.8 & 7 & 56 & 1 & 8 & 10 \\
\hline 13 & 1.0 & 3 & 30 & 1 & 10 & 0 \\
\hline 14 & 0.6 & 3 & 18 & 1 & 6 & 2 \\
\hline 15 & 1.1 & 12 & 132 & 3 & 33 & 6 \\
\hline 16 & 1.2 & 4 & 48 & 1 & 12 & 5 \\
\hline 17 & 0.6 & 6 & 36 & 2 & 12 & 12 \\
\hline 18 & 1.0 & 0 & 0 & 0 & 0 & 2 \\
\hline
\end{tabular}


Vol 21 No 1

January 2021

\begin{tabular}{|c|c|c|c|c|c|c|}
\hline 19 & 0.7 & 4 & 28 & 1 & 7 & 0 \\
\hline 20 & 0.6 & 0 & 0 & 0 & 0 & 5 \\
\hline 21 & 0.8 & 3 & 24 & 1 & 8 & 0 \\
\hline 22 & 1.0 & 7 & 70 & 3 & 30 & 2 \\
\hline 23 & 1.2 & 3 & 36 & 1 & 12 & 6 \\
\hline 24 & 0.5 & 0 & 0 & 0 & 0 & 5 \\
\hline 25 & 1.1 & 7 & 77 & 0 & 0 & 10 \\
\hline 26 & 0.3 & 6 & 18 & 1 & 3 & 4 \\
\hline 27 & 0,8 & 0 & 0 & 0 & 0 & 7 \\
\hline 28 & 2,1 & 4 & 84 & 1 & 21 & 2 \\
\hline 29 & 0,7 & 0 & 0 & 0 & 0 & 8 \\
\hline 30 & 0,6 & 7 & 42 & 1 & 6 & 15 \\
\hline Total & 27.8 & 168 & 1575 & 31 & 305 & \\
\hline Average & 0.93 & 5.6 & 52.5 & 1.03 & 10.17 & 5.9 \\
\hline
\end{tabular}

The HDMs identification of dust samples and the SFAR of respondents were shown in Table 2. HDMs were found in 24 out of 30 dust samples, and Dermatophagoides sp. were found in 21 out of 24 dust samples with HDMs. The density of Dermatophagoides sp. were ranged between 0 - $37 \mathrm{HDM} / \mathrm{g}$ of dust, while the average density was 10.17 HDM/g of dust. The identified Dermatophagoides sp. were shown in Figure 1. The SFAR of respondents were in the range of 0-15, none of them had the maximum score. As many as 11 respondents had a score of $\geq 7$, meaning had an AR.

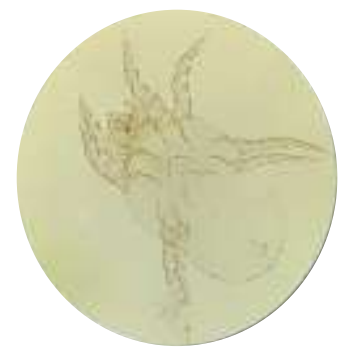

(a)

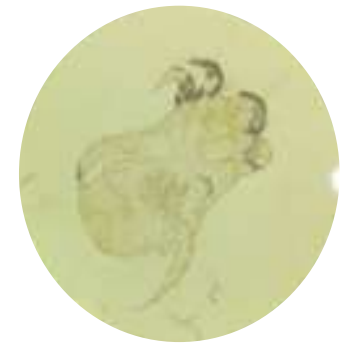

(b)

Figure 1. Morphology of Dermatophagoides sp. found in the sample (a) Female (b) Male

The data of the density of Dermatophagoides sp. were not normally distributed, so the data transformation was performed. Data were normally distributed after performing data transformation $(p=0.848)$. The test for linearity showed that the correlation between the two variables was linear $(p=0.834)$. Pearson Test to determine the correlation between the density of Dermatophagoides $s p$. and the SFAR showed $p=0.555$ and $r=0.136$. The result showed no significant correlation between the density of Dermatophagoides sp. in households and the SFAR among housewives in Jember (Table 3).

Table 3. The Result of the Statistical Analysis

\begin{tabular}{llll}
\hline & & $\begin{array}{l}\text { Density of } \\
\text { Dermatophagoides sp }\end{array}$ & SFAR \\
\hline $\begin{array}{l}\text { Density of } \\
\text { Dermatophagoides } s p\end{array}$ & $\begin{array}{l}\text { Pearson } \\
\text { Correlation } \\
\text { Sig. (2-tailed) }\end{array}$ & 1 & .136 \\
& $\mathrm{~N}$ & 21 & .555 \\
SFAR & Pearson & .136 & 21 \\
& $\begin{array}{l}\text { Correlation } \\
\text { Sig. (2-tailed) }\end{array}$ & .555 & 1 \\
& $\mathrm{~N}$ & 21 & \\
& &
\end{tabular}




\section{DISCUSSION}

In this study, women were chosen as respondents, as reported by previous studies that women have higher experience of AR than men. This might be due to a different perception of health disorders between women and men, so women had a higher intention to seek professional medical assistance than men. ${ }^{2,3,17}$ All respondents were housewives without an outside job at the time. Housewives tended to get more exposure to indoor allergens such as HDM allergens because of their daily activities such as house cleaning and households furnishings. 18,19 The majority of respondents were $25-29$ years old women (46.67\%). The previous study reported that AR's patients were mostly in productive ages, 20-29 years old, and most AR cases were 18-34 years old. AR was rarely found in a person over 60 years old due to aging process which causes the degradation of the allergen-specific level. ${ }^{20,21,22}$

Houst dust mites were identified in 24 out of 30 dust samples, and Dermatophagoides sp. were found in 21 out of 24 dust samples, while the 3 samples were having other HDMs but Dermatophagoides sp. Previous studies showed that Pyrogliphidae was a family of which dominated the identified HDMs. The most common mites of HDMs are Dermatophagoides farinae and D. Pteronyssinus. The common HDMs from other families were Blomia tropicalis, Tyrophagus putrescentiae, and Aleuroglyphhus ovatus. ${ }^{23,24}$ The density of Dermatophagoides sp. were ranged between $0-37 \mathrm{HDM} / \mathrm{g}$ of dust, while the average density was $10.17 \mathrm{HDM} / \mathrm{g}$ of dust. Dust samples were collected from mattresses, where there was an accumulation of human squama on them, which can be used as a food source of HDMs. HDMs used squama as their food source. ${ }^{25}$

The density of HDMs allergens in households is affected by multiple factors, including the physical environment and the households factors. The physical environment includes latitude, climate, seasonality, rainfall, altitude and distance from the coast. The household factors include the housing design, building age, materials, house orientation, type of furnishings, neighborhood location, ventilation, thermal system, family economic status and the number and behavior of the occupants. Our study was conducted in Jember, it is an area with the temperature range between $23-31^{\circ} \mathrm{C}$ and relative humidity $\geq 75 \%$. These conditions support the growth and development of HDMs.7,23,26 The temperature and relative humidity may increase in slums and densely populated areas. ${ }^{27}$ The negative finding of HDMs in some dust samples possibly be due to the occupants' hygiene behavior. HDMs density can be controlled by the way and frequency of the occupants to clean the house. ${ }^{28}$ Our study found a lower average HDMs density than the previous studies. ${ }^{24,25}$ We only calculated Dermatophagoides sp. density, instead of all species of HDMs.

The SFAR score showed that 11 out of 30 respondents had a score of $\geq 7$, and none of the respondents had the maximum score. None of the respondents experienced nasal symptoms in certain months, known as seasonal $A R,{ }^{28}$ causing 1 point reduction of the SFAR's score. In four-season countries, nasal symptoms can appear in certain months when pollen season comes. Since Indonesia is a two-season country, it is not easy to find seasonal AR. As we know that the SFAR was developed in France, a four-seasons country, so its application in Indonesia should be modified because the possible different allergens of both countries.

The study used the SFAR questionnaire to determine the AR. The SFAR questionnaire provided better information and more sensitive than the ISAAC questionnaire, which can not distinguish between AR and infectious rhinitis. ${ }^{10}$ But, the application of the SFAR questionnaire in Indonesia should be modified since it was established in France, a developed country, which possibly has different AR management from Indonesia. As previous study reported, socio-economic status results in differences in perception, reporting and AR symptoms management. ${ }^{10}$ Indonesia has not yet implemented allergic tests such as Skin Prick Test (SPT) or IgE serum routinely in AR's diagnosis algorithm. Hence, many AR patients know the disease without knowing the exact allergens of his/her disease. Respondents who had a total score of 5 or 6 in this study could get a total score of $\geq 7$ when carried out an allergy test andhad positive results.

Analysis using the Pearson Test showed no significant correlation between the density of Dermatophagoides sp. in households and the SFAR among housewives in Jember ( $p=0.555 ; r=0.136)$. AR is a multifactorial disease caused by the interaction between the complex environmental factors and the genetic factor of individual characters rather than a single factor, such as HDMs density. Each individual has a different level of sensitization and atopic person possesses a complex and subjective immune system. 9,23,29 Blomia tropicalis was another species which dominantly found in previous studies. Its allergens can crossreact with Dermatophagoides sp. allergens, although the incidence reported was relatively low. Lepydoglyphus sp., B. tropicalis, B. kulagini, Acarus siro, and Glycyphagus sp. were found in several Indonesia studies. Previous studies showed that AR patients were sensitive to some of those species' allergens. The insignificant correlation between variables could be due to another HDMs allergens that affect the AR symptoms as identified by the SFAR..$^{22,30,31}$ Some HDMs were found to have incomplete body parts, made difficulties in identification process, whether Dermatophagoides sp. or other species. Eggs, larvas, and 
nymphs were also found in dust samples. However, it was difficult to identify its morphological characteristic as Dermatophagoides sp. or other species. Therefore, they were not identified in this study. Those factors were the limitation of this study which may affect the results.

\section{CONCLUSION}

This study revealed no significant correlation between the density of Dermatophagoides $s p$ in households and the SFAR score among housewives in Jember, East Java.

\section{ACKNOWLEDGMENTS}

The author would like to thank all housewives who consented to participate in this study

\section{REFERENCES}

1. European Academy of Allergy and Clinical Immunology. Global Atlas of Allergic Rhinitis and Chronic Rhinosinusitis. 2015. Zurich: EAACI Headquarters.

2. Kemenkes RI. Riset Kesehatan Dasar. Badan Penelitian dan Pengembangan Kemenkes RI Jakarta. 2017. p. 118.

3. Bachet C, van Cauwenberge P \& Khaltaev N. Allergic Rhinitis and its Impact on Atshma. In Collaboration with the World Health Organization. Executive Summary of the workshop report, 7-10 December 1999, Genewa, Switzerland. Allergy, 2002; 57: 841-855. https://doi.org/10.1034/j.1398-9995.2002.23625.x

4. Habsari JT, Aryati \& Pawarti DR. Perbandingan Nilai Diagnostik IgE Spesifik Tungau Debu Rumah, Metode ELISA, dan Imunoblot pada Rinitis Alergi. Indonesian J Clin Pathol Med Lab. 2016; 22 (2): 119-126. https://doi.org/10.24293/ijcpml.v22i2.1113

5. Dullaers M, De Bruyne R, Ramadani F, Gould HJ, Gevaert P \& Lambrecht BN. The Who, Where, and When of IgE in Allergic Airway Disease. J Allergy Clin Immunol. 2012; 129 (3): p. 635-645. https://doi.org/10.1016/j.jaci.2011.10.029

6. Portnoy J, Miller JD, Williams PB, Chew GL, Miller JD, Zaitoun F. Environmental Assessment and Exposure Control of Dust Mites: a Practice Parameter. Ann Allergy Asthma Immunol. 2013; 111 (6): p. 465-507. https://doi.org/10.1016/j.anai.2013.09.018

7. Natalia D. Peranan Alergen Tungau Debu Rumah (Der p1 dan Der p2) dalam reaksi alergi. CDK; 2015; 42 (4): p. 251-255.

8. Mantu, B.G., Wahongan, G.J. \& Bernadus, J.B. Hubungan Kepadatan Tungau Debu Rumah dengan Derajat Rinitis Alergi. eBiomedik. 2016; 4 (1). https://doi.org/10.35790/ebm.4.1.2016.11056

9. Annesi-Maesano I, Didier A., Klossek M, Chanal I, Moreau D. \& Bousquet J. The Score for Allergic Rhinitis (SFAR): a Simple and Valid Assessment Method in Population Studies. Allergy: European J Allegy and Clin. Immunol. 2002; 57 (2): 107-114. https://doi.org/10.1034/j.1398-9995.2002.103170.x

10. Piau JP, Massot C, Moreau D, Ait-Khaled N, Bouayad Z, Mohammad Y, Khaldi F, et al. Assessing Allergic Rhinitis in Developing Countries. IJTLD. 2010; 14 (4): 506-512.

11. Ologe FE, Adebola SO, Dunmade AD, Adeniji, KA \& Oyejola BA. Symptom Score for Allergic Rhinitis. J Otolaryngol Head Neck Surg. 2013 April; $148 \quad$ (4): 557-563. https://doi.org/10.1177/0194599813477605

12. Purba ISE, Pijoh VD, Runtuwene J. Survey Perilaku Masyarakat terhadap Populasi Tungau Debu Rumah di Kelurahan Titiwungen Selatan Kecamatan Sario Kota Manado. Jurnal e-Biomedik. 2013 Mar; 1 (1): p. 319-324. https://doi.org/10.35790/ebm.1.1.2013.4365

13. Mantu BG, Wahongan GJ, Bernadus JB. Hubungan Kepadatan Tungau Debu Rumah dengan Derajat Rhinitis Alergi. Jurnal e-Biomedik. 2016 Jan; 4 (1). https://doi.org/10.35790/ebm.4.1.2016.11056

14. Yolazenia Y. Harianto H, Riady IT. Gambaran kepadatan tungau debu rumah sebagai pencetus rhinitis alergi pada anak panti asuhan Pekanbaru. Jurnal Ilmu Kedokteran. 2019 Mar; 13 (1): 23-27. https://doi.org/10.26891/JIK.v13i1.2019.23-27

15. Collof MJ. Dust mites. Dordrecht: Springer Netherland; 2009. https://doi.org/10.1071/9780643100497

16. Kawulur YC, Tuda JS, dan Wahongan GJ. Jenis dan Kepadatan Tungau Debu Rumah yang Ditemukan di Kelurahan Teling Bawah Kecamatan Wenang Kota Manado. eBiomedik. 2013; 1 (3): 1081-1084. https://doi.org/10.35790/ebm.1.3.2013.3263

17. Rambe AY, Fadhlia M, Munir D, Haryuna, TSH, dan Eyanoer PC. Hubungan Rinitis Alergi dan Disfungsi Tuba Eustachius dengan menggunakan Timpanometri. ORLI. 2013; 43 (1): p. 80-89. https://doi.org/10.32637/orli.v43i1.20

18. Novitasari, Sorisi A, dan Wahongan GJP. Profil Penderita Alergi dengan Hasil Skin Prick test TDR Positif di Poliklinik Alergi-Imunologi RSUP Prof. Dr. R. D. Kandou Manado periode 2007-2009. eBiomedik. 2013; 1 (2): p. 1014-1018. https://doi.org/10.35790/ebm.1.2.2013.3254 
19. Reinhard E, Palandeng OI, dan Pelealu OC. Rinitis alergi di Poliklinik THT-KL BLU RSU Prof. dr. RD Kandou Manado periode Januari 2010-Desember 2012. e-CliniC. 2013; 1 (2). https://doi.org/10.35790/ecl.1.2.2013.3280

20. Susanti E, Pawarti DR, dan Soeprijadi S. Hubungan Kadar RANTES Sekret Hidung dengan Skor Gejala Total Penderita Rinitis Alergi. ORLI. 2016; 46 (2): p. 110-120. https://doi.org/10.32637/orli.v46i2.158

21. Rahmawati N, Suprihati S, dan Muyassaroh M. Faktor Risiko yang Mempengaruhi Disfungsi Tuba eustachius pada Penderita Rinitis Alergi Persisten. ORLI. 2011; 41 (2): 142-146. https://doi.org/10.32637/orli.v41i2.51

22. Cazzoletti L, Ferrari M, Olivieri M, Verlato G, Antonicelli L, Bono R., et al. The Gender, Age and Risk Factor Distribution Differs in Self-reported Allergic and Non-allergic Rhinitis: a Cross-sectional Population-based Study. Allergy Asthma Clin Immunol. 2015; 11 (1): 36-44. https://doi.org/10.1186/s13223-015-0101-1

23. Yu JM, Luo QH, Sun JL, Shi CL, Yin J, Zhou YL., et al. Diversity of House Dust Mite Species in Xishuangbanna Dai: a Tropical Rainforest Region in Southwest China. BioMed research international. 2015; p. 1-6. https://doi.org/10.1155/2015/421716

24. Ponggalunggu WF, Pijoh VD, \& Wahongan GJ. Jenis dan Kepadatan Tungau Debu Rumah pada Beberapa Habitat di Rumah Penderita Penyakit Alergi. eBiomedik. 2015; 3 (1): p. 254-260. https://doi.org/10.35790/ebm.3.1.2015.6734

25. De Breving RFR., Tuda JSB \& Wahongan GJP. Tungau Debu Rumah yang Ditemukan di Kelurahan Perkamil Kecamatan Paal 2 Kota Manado. eBiomedik. 2013; 1 (2): p. 859-862. https://doi.org/10.35790/ebm.1.2.2013.5471

26. Badan Perencanaan Pembangunan Daerah Provinsi Jawa Timur. Potensi dan Produk Unggulan Jawa Timur. 2013. Surabaya: Badan Perencanaan Pembangunan Daerah Provinsi Jawa Timur.

27. Badan Pusat Statistik Kabupaten Jember. Kecamatan Sumbersari dalam Angka. Jember: Badan Pusat Statistik Kabupaten Jember. 2018.

28. Soltani A, Azizi K, Saleh V \& Dabaghmanesh T. The Fauna and Distribution of House Dust Mites in Residential Homes of Bandar Abbas District, Southern Iran. Exp Appl Acarol. 2011; 54 (3): p. 269-276. https://doi.org/10.1007/s10493-011-9436-6

29. Bousquet J, Khaltaev N, Cruz AA, Denburg J, Fokkens W, Togias A, et al. Allergic Rhinitis and its Impact on Asthma (ARIA) 2008 update (in collaboration with the World Health Organization, GA2LEN, and AllerGen). Allergy. 2008; 63 (Suppl. 86): p. 8-160.

30. Haqi, S.A. 2016. Prevalensi dan Derajat Infestasi Tungau Debu Rumah di Asrama Mahasiswa [disserattion]. Bogor: Institut Pertanian Bogor.

31. Sade K, Roitman D \& Kivity S. Sensitization to Dermatophagoides, Blomia tropicalis, and other mites in atopic patients. J Asthma. 2010; 47 (8): 849-852. https://doi.org/10.3109/02770903.2010.506683 